\title{
FEASIBILITY OF MUNICIPAL WASTE REUSE FOR BUILDING ENVELOPES FOR NEAR ZERO-ENERGY BUILDINGS
}

\author{
ROSSELLA ROVERSI ${ }^{1}$, FABRIZIO CUMO ${ }^{2}$, ALESSIA D'ANGELO ${ }^{2}$, \\ ELISA PENNACCHIA ${ }^{2} \&$ GIUSEPPE PIRAS ${ }^{3}$ \\ ${ }^{1}$ Interdepartmental Centre for Territory, Building, Conservation and Environment, \\ Sapienza University of Rome, Italy \\ ${ }^{2}$ Department of Planning Design and Technology of Architecture, Sapienza University of Rome, Italy \\ ${ }^{3}$ Department of Astronautical, Electrical and Energy Engineering, Sapienza University of Rome, Italy
}

\begin{abstract}
This paper deals with the experimental stage of an Italian research project aimed at testing the feasibility of municipal waste reuse for the designing of building envelopes for Zero-Energy Buildings. The first stage dealt with the designing of the single components, whilst the stage described in the present contribution is about the project for a pilot didactic class for the Mira Porte Primary school, located in the town of Mira (Venice, Italy). It is the result of a research agreement between the Interdepartmental Centre for Territory, Building, Conservation and Environment of the Sapienza University of Rome (CITERA) and the Municipality of Mira. Energy efficiency of public buildings and the creation of safe and healthy schools are central topics in current national and local Italian politics, topics which include incentives and funds. The paper describes the main architectural, technological and plant characteristics of the classroom project. The building is an NZEB, configured as an additional independent volume, placed in the courtyard of the existing school. It is composed of a room for 25 students and an adjoining winter garden which has both a bioclimatic and a didactic function. The main feature of the project is the use of prefab building components made from solid urban waste, in particular wooden pallets and tyres, instead of traditional building materials, so as to contribute to a decreasing demand for energy and improve eco-friendly waste management. The present experiment aims at demonstrating the behaviour of the components once they have been assembled into a built structure and the overall functioning of the building structure and its systems.
\end{abstract}

Keywords: school buildings, Near Zero Energy Buildings, municipal waste reuse, solid waste up-cycling, prefab building components.

\section{INTRODUCTION}

In Italy, proposal D.L. 04/06/2013, n. 63, converted into Law 03/08/2013, n. 90, establishes the criteria for the updating and planning of performance standards for buildings with the aim to achieve the targets set by Directive 2010/31/EU "Energy Performance Building Directive" (EPBD), which introduces Near Zero Energy Buildings (NZEB) [1]. D.L. n. 63/2013 establishes that starting from 2019 all buildings occupied by Public Administrations and property of the latter, including school buildings, shall be NZEB; it furthermore establishes that from $1^{\text {st }}$ January 2021 all newly built buildings shall also be NZEB. Italian Regions have later legislated autonomously in this respect and some have anticipated such deadlines.

The National Energy Strategy provides for a strengthening of incentive measures for interventions on real estate assets of the Public Administration to which is attributed a guiding and exemplary role for the entire energy efficiency building construction sector, and the building of schools, due to their vast number and remarkable social importance, represents a priority field of action [2]. In Italy, buildings being solely or mostly schoolhouses are approximately 51.000 on a surface of 73 million sq. $\mathrm{m}$ with a volume of 256 million cubic meters [3]. According to the 2015 Report by the School Construction Registry and the Ministry of Education University and Research (MIUR), on a surveyed sample of 33.825 
active school buildings, 55\% were built before 1976, thus they now present obsolete features, especially with regard to energy aspects, fire prevention and seismic risk. Only one fourth of schools complies with all the certifications assessing static safety, power system safety and hygienic conditions. Furthermore, a total of about 13.500 schools are located in areas of high seismic hazard.

In Italy, competences related to the building of schools lie with Local Authorities which, however, require frequent deployment of state resources in order to carry out interventions of any significance [4]. The Italian Government has started a plan for urban regeneration and renewal of school building assets according to criteria of environmental sustainability, architectural quality, safety and law compliance. The Ministry of Public Works, with the scientific support of the University, provided for the updating and improvement of its technical legislation concerning the planning and restoration of school buildings with the aim of reviewing and integrating this same legislation according to future needs [5]. New Guidelines for Interior Architecture in Schools, published in April 2013, deviate from the prescribed requirements previously established by D.M. 18/12/1975, embracing a performance-based logic, proposing modular flexible spaces, easily adaptable to different educational contexts. The updating of the requirements in terms of environmental well-being and protection has been one of the most important goals of the guidelines. In particular a new category of requirements has been introduced related to the Protection and Respect of the Natural Environment. The section of the regulations concerning Environmental Compatibility has been developed according to the following categories: soil resources, water resources, material resources, energy resources. In accordance with the afore mentioned requirements, the structure of the revised technical legislation which governs school buildings includes some indicative behaviors and actions which are useful for achieving the environmental compatibility of both new and restoration work on school buildings.

Interventions relative to school buildings can be a particularly suitable occasion for experimenting environmentally-conscious design principles, with a bio-climatic approach and the application of innovative technologies, both for the type of usage and for the requirements of these spaces [6]. Last but not least, they are designated places of learning and thus represent an educational tool in themselves, also through the involvement of students in the management of the buildings, their monitoring and the assessment and diffusion of results in terms of performance.

\section{PROJECT STRATEGIES AND ARCHITECTURAL SOLUTIONS}

The present contribution deals with the experimental project for a didactic classroom to be created as the enlargement of an existing school building: the Mira Porte primary school located in the Municipality of Mira, in the province of Venice. It is the result of a research agreement between the Interdepartmental Centre for Territory, Building, Conservation and Environment of the Sapienza University of Rome (CITERA) and the Municipality of Mira.

The research puts together three fundamental subjects: the use of waste as a resource, the design of eco-innovative and energy efficient solutions for envelopes and the verification of their effectiveness and feasibility in order to be used in ZEB buildings [7]. The agreement with the Municipality of Mira foresees the designing, carrying out and post operam monitoring of a building module of about 100 total sq. m, distributed over a single floor and divided into a didactic classroom and a winter garden. 

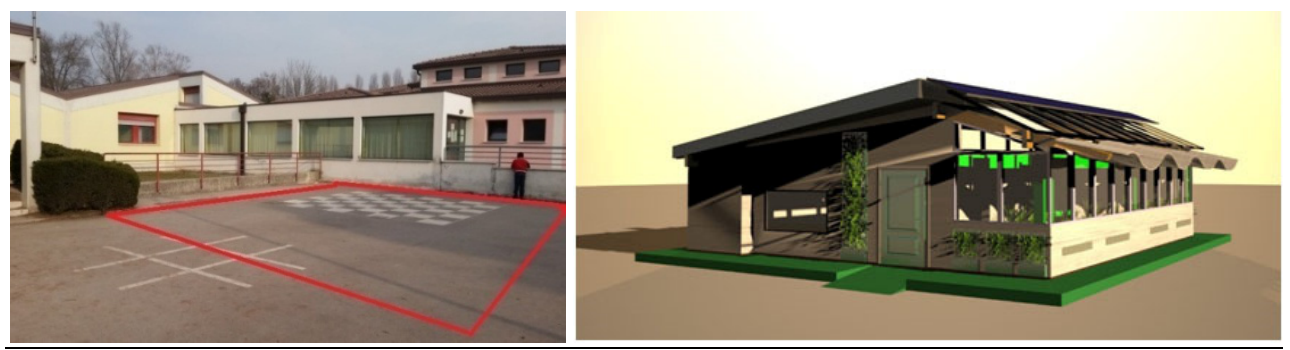

Figure 1: The site of the designed project of the new classroom in the "Mira Porte" School and the BIM model of the building in the summer version.

The opaque envelope of the building is made with building components which are the fruit of the up-cycling of some types of solid urban waste: the project for the classroom was preceded by a first research stage aimed at the study of the single building components to assess their performance and compliance with Italian laws on building construction and energy [8]. The economic costs of the building envelope structures were assessed and compared with common building wall structures with the same thermal transmittance, to verify the potential appeal on the Italian building market. The acoustic characterization of each component was calculated to ensure compliance with the Italian rules on sound insulation on external walls [9]. The present experiment aims at demonstrating the authentic behaviour of the components once they have been assembled into a built structure and the overall functioning of the building structure and its systems.

The new building, the creation of which will be financed by the Municipality of Mira and the monitoring of which will represent the final research stage, will be placed in the courtyard of the existing school and will be connected to it through an indoor corridor located near the entrance door to the school itself. The building has been designed in compliance with laws provided for by D.M. 18/12/1975 "Updated technical standards for school buildings, including didactic functionality, building and urban planning indexes" and subsequent modifications and integrations, as well as following the "Guidelines for the interior architecture of schools". The space comprises two adjoining spaces: a classroom for didactic activities, of about 60 sq. m (walls excluded), which will house children, and a winter garden of about 20 sq. $\mathrm{m}$ which, as well as playing an essential role from a bio-climatic perspective, will house a vegetable garden dedicated to inquiry learning, to broaden the knowledge and sensitivity of little ones on sustainability and nutrition topics [10].

To meet energy efficiency criteria, salubrity and comfort, the project for the building employs bio-climatic designing and the combining of active and passive solar systems, calibrated according to the climatic features of the surrounding area. The compact shape of the building derives from the necessity to have a low surface-volume ratio, so as to limit heat loss. Southern exposure of the winter garden allows for improved solar gain: the objective is to ensure maximum direct sun exposure and natural illumination of the classroom but at the same time the use of screens allows for the adaptability and adjustability of winter and summer assets [11]. 


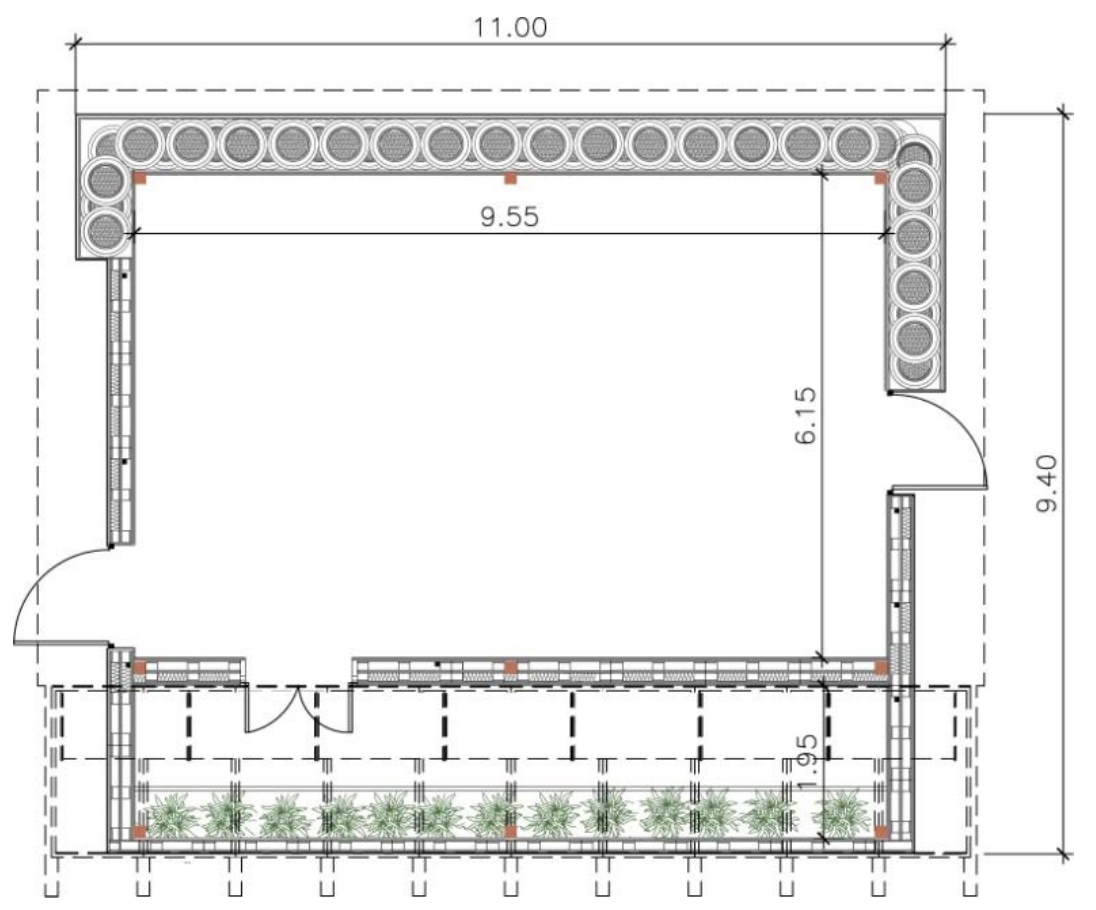

Figure 2: The plant of the building that hosts a classroom and a winter-garden (in meters).

Transparent dividing elements between the greenhouse and the outside are characterized by a 0.8 -solar factor and are opaque compared to the infrared wave lengths, a spectrum which characterizes the radiation emitted by the surfaces at the temperatures of interest; slabs in compact polycarbonate have been chosen to integrate the high shock and temperature resistance with optimal transparency. The large windows allow to capture over 3.300 $\mathrm{KWh} /$ year and activate natural ventilation: cold air penetrates through the vents placed on the southern side, it is heated while passing through the greenhouse and is then expelled by a ventilation chimney situated in the classroom. The position of the windows allows for the arrival of ulterior natural light to the work surfaces and desks mainly from the left, thus maximizing illumination.

In addition, transparent coverage surfaces have been foreseen, in correspondence with the solar greenhouse. To avoid burdening the cooling load horizontal skylights have been avoided and inclined glass windows have been preferred, if necessary screened by roller blinds, so as to impede access to direct radiation during the summer and direct the radiation towards the inside in winter.

Heat accumulation from passive solar heat gain is entrusted to the walls with greater thermal inertia, facing North, East and West.

The main design strategies are completed by the introduction of a hybrid ventilation system, to ensure environmental comfort under any condition of usage, a meteoric water recovery plant, used for the irrigation of the plants grown in the winter garden and for washbasins, and exploitation of solar energy through the installation of a photovoltaic and a solar thermal plant. 


\section{THE BUILDING ENVELOPE}

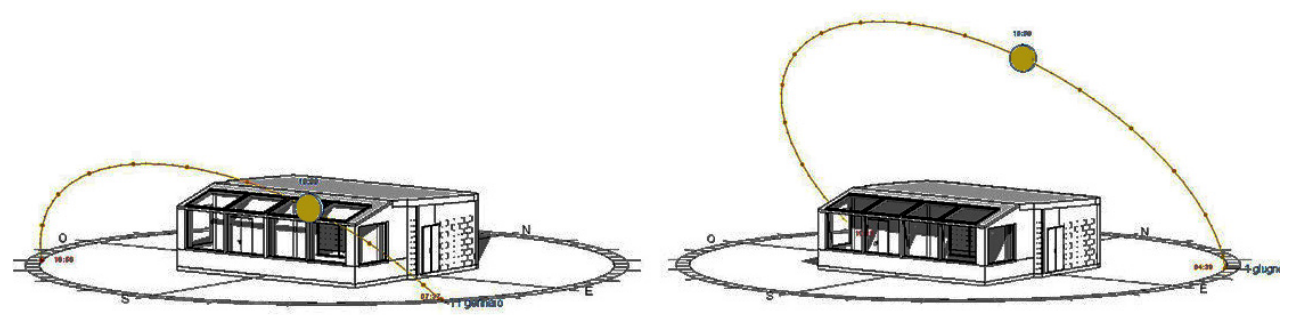

Figure 3: Simulate analysis of sunshine in January and June.

As already mentioned, the previous step of the research aimed at illustrating the possibilities of the reuse of municipal waste for designing vertical and horizontal closures for ZEB, so different typologies of municipal waste have been selected and analyzed in order to check their availability and to verify the feasibility of their assembly in newly designed building components: tyres, wood pallets, cardboard tubes, glass and plastic bottles [12]. All the municipal waste considered in the research is used as infill in assembled modules and needs a wooden complementary primary structure.

First, real models were made by the authors, assembling the selected waste materials in order to establish the most suitable dimensions and proportions of the components and identify the assembly methods. Once geometric characteristics and size had been established, thermal and acoustic behaviours were calculated to verify their efficiency. The components were designed using different municipal wastes while maintaining for each structure a thermal transmittance (U) of about $0.25 \mathrm{~W} / \mathrm{m}^{2} \mathrm{~K}$, calculated according to UNI EN ISO 13790 on thermal behaviour in buildings [13].

The present step of the research designs the envelope of the school building using prefab components based on the up-cycling of about 350 wood pallets and 300 car tyres.

\subsection{Vertical closure made with tyres}

The walls made through the reuse of tyres are those where high levels of mass and thermal inertia occur. In the case of the classroom in Mira, they are the wall facing North and part of the one facing East. The application requires the presence of two male-female complementary modules, composed of 5 (female) or 4 (male) tyres joined together by means of staples. The tyres are filled with compressed straw, a well-known material for its sustainability, it's very low environmental impact and its performance as a blocking material in walls.

\subsection{Vertical and horizontal closure made with pallets}

Wood pallets are the most common and cheapest wood structure for reuse among urban waste. A 34-cm-thick model has been realized using two pallets and two OSB panels. The model has been insulated to get a $0.25 \mathrm{~W} / \mathrm{m} 2 \mathrm{~K}$ thermal transmittance filling in the wood pallets with wood fibre. The outside walls of the classroom made of pallets are those facing West, part of the one facing East and the South wall, in the closed part under the windows of the solar greenhouse, where no insulating fittings are present. In addition, this component is used for the wall which divides the classroom from the greenhouse. This component is also 
used for coverage and as a ventilated under-floor cavity, housing a double pallet on a sheath layer.

Table 1: Building component made from reused tyres.

\begin{tabular}{|l|l|}
\hline $\begin{array}{l}\text { Tyres } \\
\text { Component }\end{array}$ & $\begin{array}{l}\text { Description and data } \\
\text { modules, joined together by means of } \\
\text { staples: } \\
\text { - male module composed of } 3 \text { tyres } \\
\text { - female module composed of } 3 \text { tyres }\end{array}$ \\
\hline $\begin{array}{l}\text { Insulating } \\
\text { filling }\end{array}$ & $\begin{array}{l}\text { Compressed straw } \\
\text { Total component thickness: } 640 \mathrm{~mm} / \mathrm{T} 20 \\
\text { mm with external ventilation slot }\end{array}$ \\
\hline Dimensions & $\begin{array}{l}\text { OSB panels joined to the tyres by threaded } \\
\text { tie rods, with plaster (internal face) or } \\
\text { ventilation camera with wood panel } \\
\text { (external face). }\end{array}$ \\
\hline $\begin{array}{l}\text { Internal and } \\
\text { external } \\
\text { finishing }\end{array}$ & $\begin{array}{l}\text { Vertical closure: } \\
\text { wall facing North and part of the wall } \\
\text { facing East }\end{array}$ \\
\hline Placing &
\end{tabular}

Table 2: Building component made from reused pallets.

\begin{tabular}{|l|l|}
\hline $\begin{array}{l}\text { Wood pallets } \\
\text { Component }\end{array}$ & Description and data \\
\hline Structure & $\begin{array}{l}\text { Single wood pallet component or double } \\
\text { overlying wood pallet component }\end{array}$ \\
\hline Insulating filling & $\begin{array}{l}\text { Sood fibre panels } \\
\text { double pallet total component thickness: } 330 \\
\text { mm }\end{array}$ \\
\hline Dimensions & $0.24 \mathrm{~W} / \mathrm{m}^{2} \mathrm{~K}$ \\
\hline Transmittance & $\begin{array}{l}\text { OSB panels with plaster (internal and } \\
\text { external) } \\
\text { external antal } \\
\text { finishing }\end{array}$ \\
\hline Placing & $\begin{array}{l}\text { Vertical closure: walls facing West and } \\
\text { South, part of the wall facing East. } \\
\text { Internal partition: between the classroom and } \\
\text { the winter-garden Ground floor ventilation } \\
\text { space }\end{array}$ \\
\hline
\end{tabular}




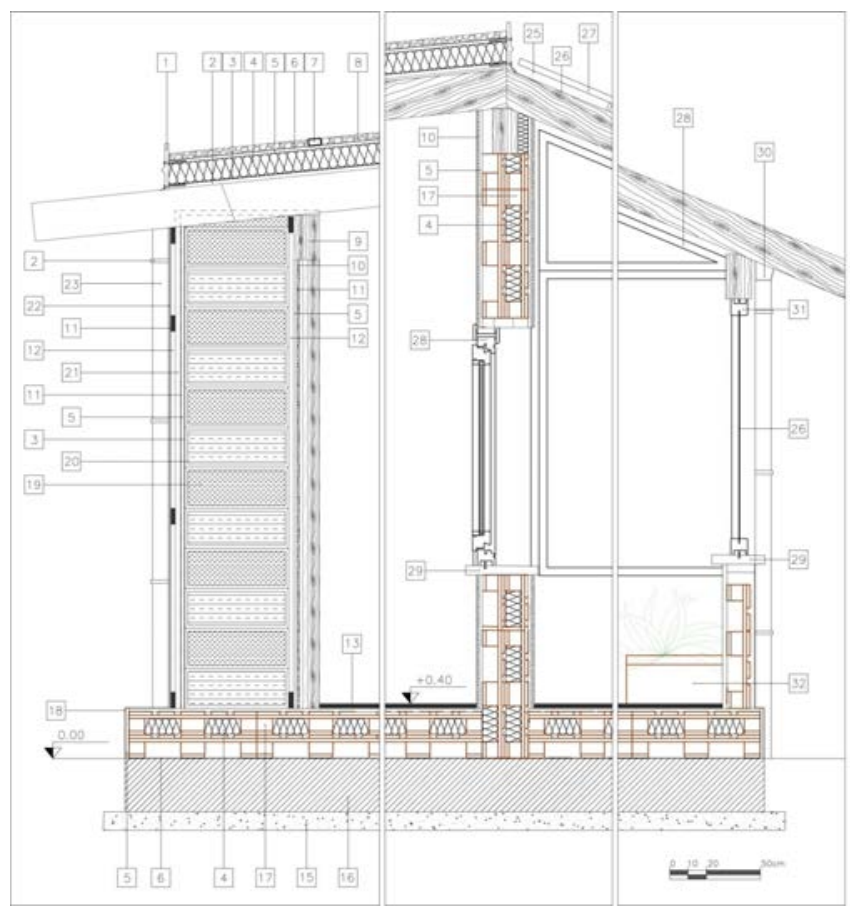

Figure 4: Vertical section of the architectural executive project for the classroom and the winter garden.

Table 3: Legend of the vertical section in Fig 4.

\begin{tabular}{|l|l|}
\hline Legend of the section & 18. Brush applied liquid sheath \\
\hline 1. Metallic flashing & 19. Insulation in compressed straw \\
\hline 2. Wooden planking $(2,5 \mathrm{~cm})$ & 20. Tyre \\
\hline 3. Steam barrier $(0,022)$ & 21. Tyres fastenings \\
\hline 4. Insulation in wooden fibre $(13 \mathrm{~cm})$ & 22. External coating panel $(0,8 \mathrm{~cm})$ \\
\hline 5. OSB Panel $(2 \mathrm{~cm})$ & 23. Waterspout \\
\hline 6. Sheath $(0,4 \mathrm{~cm})$ & 24. Gutter support \\
\hline 7. Stabilizer gravel upright & 25. Photovoltaic panel support \\
\hline 8. Gravel $(4 \mathrm{~cm})$ & 26. Compact polycarbonate panel \\
\hline 9. Secondary wooden beam & 27. Photovoltaic panel \\
\hline 10. Plaster $(1,5 \mathrm{~cm})$ & 28. Fixed window frame \\
\hline 11. Metal joint & 29. Threshold \\
\hline 12. Wooden upright & 30. Gutter \\
\hline 13. Recycled rubber safety floor $(3 \mathrm{~cm})$ & 31. Window frame (greenhouse) \\
\hline 14. Bearing wooden pillar & 32. Planters \\
\hline 15. Levelling concrete layer $(10 \mathrm{~cm})$ & \\
\hline 16. Concrete foundation slab $(40 \mathrm{~cm})$ & \\
\hline 17. Double Pallet & \\
\hline
\end{tabular}




\section{ACOUSTIC AND ECONOMIC COST ASSESSMENT RESULTS}

Table 4: Sound Reduction Index and cost evaluation of envelopes made from tyres or pallets compared to traditional components with the same thermal performance.

\begin{tabular}{|l|c|c|c|c|c|}
\hline $\begin{array}{l}\text { Designed } \\
\text { Model }\end{array}$ & $\begin{array}{l}\text { Thermal } \\
\text { Transmittance } \\
\mathrm{U}\left(\mathrm{W} / \mathrm{m}^{2} \mathrm{~K}\right)\end{array}$ & $\begin{array}{l}\text { Soundproofing } \\
\mathrm{Rw}(\mathrm{dB})\end{array}$ & $\begin{array}{l}\text { Dimension } \\
\left(\mathrm{m}^{2}\right)\end{array}$ & Cost $(€)$ & $\begin{array}{l}\text { Parametric } \\
\text { Cost }\left(€ / \mathrm{m}^{2}\right)\end{array}$ \\
\hline Tyres & 0.24 & 61.00 & 0.65 & 40.30 & 62.00 \\
\hline $\begin{array}{l}\text { Wood } \\
\text { pallets }\end{array}$ & 0.24 & 56.50 & 0.96 & 67.20 & 70.00 \\
\hline $\begin{array}{l}\text { Traditional } \\
\text { envelope } \\
\text { structure in } \\
\text { bricks }\end{array}$ & 0.24 & 48.00 & 1.00 & 80.00 & 80.00 \\
\hline
\end{tabular}

The calculated values of Weighted Sound Reduction Index (Rw) for the two components are listed in Table 4. Both the obtained values are in compliance with the Italian regulation on the acoustic performance of building envelopes (D.P.C.M. 5/12/97 Buildings Passive Acoustic Requirements Determination).

The economic costs of the designed building envelope made of up-cycled waste have been estimated for each component by consulting the Italian consortiums dealing with the reuse and recycle of tyres (Ecopneus) and wood (Rilegno). Then, since each model has different dimensions, a parametric cost per square meter has been evaluated.

The economic costs of the above-described building envelope structures have been compared with a common building wall structure, composed of $1.5 \mathrm{~cm}$ of plaster (internal and external), $8 \mathrm{~cm}$ of perforated brick, $12 \mathrm{~cm}$ of insulating material, $12 \mathrm{~cm}$ of perforated brick, dimensioned to have the same thermal transmittance of the innovative wall structure $(\mathrm{U}=0.24 \mathrm{~W} / \mathrm{m} 2 \mathrm{~K})$ made of reused materials. Its economic cost, $80 €$ per square meter, has been obtained on consulting a traditional price list for common building materials [14]. The thermal transmittance being equal, the results obtained highlight the fact that the building envelope structure reusing tyres is the cheaper option. Both envelopes made of tyres and wood pallets are cheaper than the traditional one (see Table 3).

\section{BEARING AND STIFFENING STRUCTURES}

The bearing structure in the building was designed in accordance to the existing seismic laws (D.M. 14/01/2008). According to the Italian seismic classification of territories, the Municipality of Mira is in a level 4 seismic zone (OPCM n. 3274 of 20/03/2003. The structure is made of cross-laminated timber GL24h; it is made up of 9 wooden pillars in sections of $16 \times 16 \mathrm{~cm}, 3$ primary warping beams in on sight cross-laminated timber in sections of $16 \times 28 \mathrm{~cm}$, and 27 small secondary warping beams in exposed cross-laminated timber in sections of $14 \times 24 \mathrm{~cm}$. The foundations are made of reinforced concrete slabs.

The stiffening system of the wall made with the pallet elements is made up of section struts of $6 \times 6 \mathrm{~cm}$ placed within the space which is generally used for anchoring the forks and connected by means of metallic joints to the small beams in the covering structure and to the basic slab.

The walls made of modules in tyre are also stiffened by fixing cross-laminated timber struts to the coverage and the floor slab, positioned externally along the vertical axis joining the points in which the male and a female module are joined. The struts are fixed to the floor 


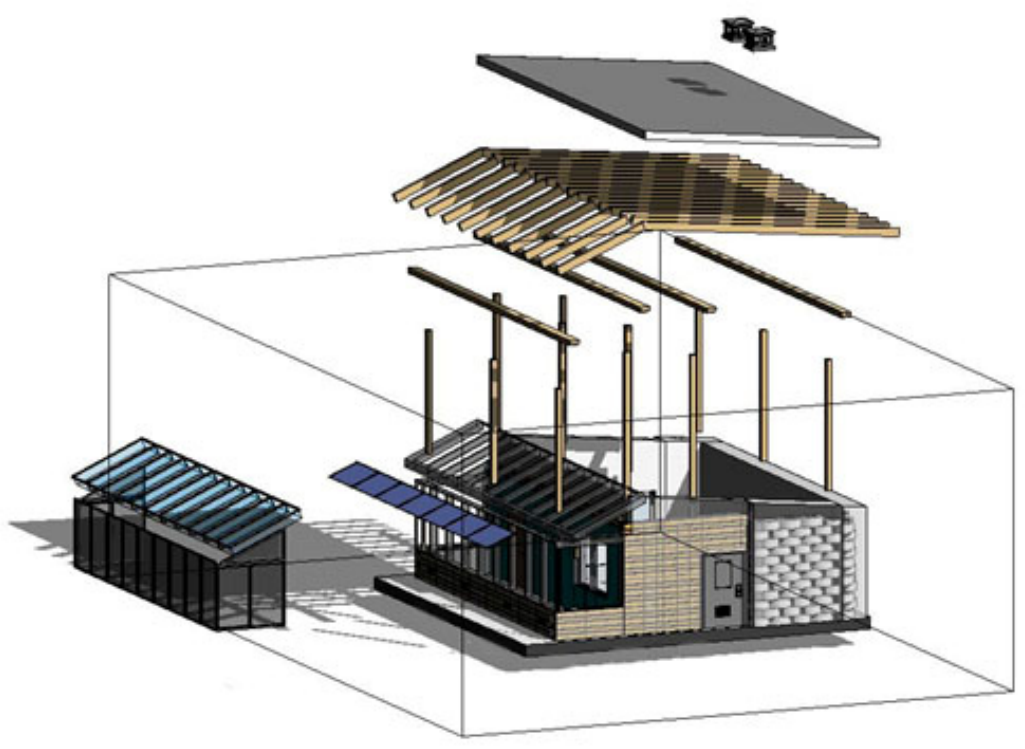

Figure 5: Exploded BIM model of the building.

slab by means of bolted plates and to the coverage by means of rivets and to the tyres with self-fastening nylon bands. In the interior environment, the tyre modules are fastened to the OSB panels by means of metal butterfly screws.

\section{POWER SYSTEMS AND PLANTS}

As far as heating and electrical power supply are concerned, the designed building shows lower energy consumption than the quantity of energy it produces.

Production of electricity is obtained by installing 7 monocrystalline photovoltaic panels onto the inclined part of the roof and facing South, for an overall peak power of $1.7 \mathrm{~kW}$. Panels are connected by means of an inverter to the existing electrical network, thus allowing for an on-site exchange between the energy produced by the photovoltaic panels and that coming from the national network. During July and August the school is not in regular use, while the autonomous systems of electrical energy continue generating energy with high gains related to solar radiation. From September to April the estimated thermal energy demand is $12,520.8 \mathrm{MJ}$, the solar supplies guaranteed by the greenhouse, in the same period, are 16,662.3 MJ. The heating, cooling and ventilation system in the classroom is based on a hybrid system, to meet eventual peaks of winter and summer heat loads: two 3-kW air to air heat pumps are present, while the designed natural ventilation system is integrated by two $250 \mathrm{mc} / \mathrm{h}$ fans, placed onto the wall at the end of the room and which can be started by a flow stitch, in the case of excessively low air speed in the environment. These hybrid systems only necessitate electrical power supply. The Energy Performance Index of the building, calculated according to D.M. 26/06/2015, is $92.5 \mathrm{kWh} / \mathrm{m}^{2}$ year (A3 class).

The water system foresees the reintegration and recuperation of rain water, according to standard design technologies for non-drinking indoor purposes. The main use for the recuperated water foreseen for the didactic classroom involves the irrigation of the green areas inside the solar greenhouse (60 litres per sq. $\mathrm{m} / \mathrm{year}$ ). The plant was sized according to 
the rainfall chart for the area where the project was located (Venice), where the yearly average figure for rainfall is $1708 \mathrm{~mm}$.

\section{CONCLUSIONS}

The school building designed represents an experimental prototype of Near Zero Energy Building, the particularity of which lies in the use of prefab building components made from solid urban waste instead of traditional materials. As stated in the first stage of the research, local municipal waste can be reused for building envelope structures, guaranteeing the same thermal and acoustic performance with similar or lower economic costs [15], The present pilot project, integrates the high energy efficient envelope with the use of renewable energy sources and passive and active sustainable technologies and strategies.

Its environmental sustainability has been verified applying the Italian ITACA Protocol for School Buildings: the final synthetic evaluation class is 5, i.e. it is regarded as a considerably advanced performance compared to the best current constructive practices, considering all the stages of the building, from its realization to its future dismissal [16].

The main advantageous and distinguishing features of the reuse of municipal solid waste as building components can be summarized as follows:

- the reduction of production times and site preparation thanks to the prefab construction and dry-assembly techniques based on the simplicity of implementation;

- the possibility of selected demolition and the easy reinsertion in the recycling process;

- the combination of the selected wastes with the insertion of thermal and acoustical insulating materials improves component performance and allow for law compliance;

- the reuse of local waste materials for energy efficient building structures, designed without particular treatments, is an effective, low-cost and environmentally sustainable waste management strategy that avoids the usual recycling industrial processes and saves on the tremendous amount of energy expenditure required for the production of recycled elements;

- the availability of common municipal solid waste in the vicinity of the place where the components are produced and where they will be used, further reduces the environmental impact resulting from transportation of the waste.

Italian public buildings represent an important opportunity for experimenting new building systems and technologies, being the first that are required to comply with Directive 2010/31/EU, and generally being old and inadequate for the needs of their users. School buildings are particularly suitable for renewal interventions aimed at complying with modern requirements for safety, energy saving and comfort as well as easily adaptable to new didactic methods and ICT technologies [17]. The municipality involved in the Mira classroom project contributed by making available the area, the resources and its know-how, in the awareness that it would represent an experimental didactic module, easily replicable or adjustable to other contexts and that more sustainable school buildings are a valid vehicle for the forming of an environmentally-conscious cultural background of students.

\section{ACKNOWLEDGEMENTS}

We thank the Municipality of Mira and Riccardo Fraccaro. 


\section{REFERENCES}

[1] European Parliament, Directive 2010/31/EU of the European Parliament and the council on the energy performance of buildings (EPDB), Off. J. Eur. Union, 12, pp. 124-146, 2010.

[2] Ministero dello Sviluppo Economico, Strategia Energetica Nazionale 2017, available at www.dgsaie.mise.gov.it. Accessed on: 20 Aug. 2017.

[3] ENEA, RSE, CTI, Ministero dello Sviluppo Economico, PANZEB Piano d'Azione Nazionale per incrementare gli edifici ad energia quasi zero: Rome, 2016.

[4] IIV Commissione della Camera dei Deputati, XVII Legislatura, Documento finale dell'Indagine conoscitiva sull'edilizia scolastica in Italia, Bollettino delle Giunte e delle Commissioni Parlamentari, Cultura, Scienza, Istruzione, 2 Aug. 2017.

[5] MIUR, Linee guida per le architetture interne delle scuole, 11 Apr. 2013, available at www.hub.miur.pubblica.istruzione.it. Accessed on: 13 Aug. 2017.

[6] Borri, S., Spazi educativi e architetture scolastiche: linee e indirizzi internazionali, INDIRE: Firenze, 2016.

[7] Astiaso Garcia, D., Carbonara, E., Cumo, F., Pennacchia, E. \& Tiberi, M.G., Reuse and Upcycling of Municipal Waste for ZEB Envelope Design in European Urban Areas, Sustainability 8, p. 610, 2016.

[8] Cumo, F., Pennacchia, E. \& Sferra, A., Uso Disuso Riuso. Criteri e modalità per il riuso dei rifiuti come materiale per l'edilizia, Franco Angeli: Milano, 2015.

[9] Aureli, C., Cumo, F., Pennacchia, E., Piras, G. \& Roversi, R., Reuse of municipal waste for high performance building components, Construction \& Building Materials, to be published.

[10] Linee guida educazione ambientale del Ministero dell'Ambiente e della Tutela del Territorio e del Mare, MATTM: Rome, 2015.

[11] Scognamiglio, A., Aelenei, L., Aelenei, D., Gonclalves, H., Lollini, L., Musall, E., Cubi, E. \& Noguchi, M., Design issues for net-zero energy buildings, Open House International, 38(3), pp. 7-14, 2013.

[12] U.S. Environmental Protection Agency, Office of Solid Wastes, Test Methods for Evaluating Solid Wastes, Physical/Chemical Methods, available at www.epa.gov/epaoswer/hazwastes/test/main.htm. Accessed on: 23 Jun. 2016.

[13] Baglivo, C., Congedo, P.M., Fazio, A. \& Laforgia, D., Multi-objective optimization analysis for high efficiency external walls of zero energy buildings (ZEB) in the Mediterranean climate, Energy Build., 84, pp. 483-492, 2014.

[14] DEI, Prezzi Informativi dell'Edilizia. Nuove Costruzioni. Materiali ed Opere Compiute (4th ed.), Tipografia del Genio Civile: Rome, 2015.

[15] Becchio, C. \& Ghiglione, C., NZEB Design: Challenging between Energy and Economic Targets, Energy Procedia, 78, pp. 2070-2075, 2015.

[16] Hossaini N., Hewage, K. \& Sadiq, R., Spatial life cycle sustainability assessment: a conceptual framework for net-zero buildings, Clean Technologies and Environmental Policy, 17(8), pp. 2243-2253, 2015.

[17] Boarin, P., Riqualificazione energetica e ambientale dell'edilizia scolastica. Immagini, obiettivi, strategie, EprintsUnife, available at www.eprints.unife.it, 2009. Accessed on 15 Apr. 2016. 